\title{
CARTOGRAFIAS AFETIVAS E MAPAS SOBREPOSTOS: NOTAS SOBRE A POESIA DE MARÍLIA GARCIA
}

\section{AFFECTIVE CARTOGRAPHIES AND OVERLAY MAPS: SOME NOTES ON POETRY OF MARILIA GARCIA}

\author{
Rosicley Andrade Coimbra' \\ [Orcid: https://orcid.org/0000-0002-2206-4801] \\ DOI: https://doi.org/10.30612/raido.v14i36.12647
}

RESUMO: O objetivo deste artigo é tecer algumas consideraçōes acerca da poesia de Marília Garcia tomando como pretexto inicial a ideia de rizoma de Gilles Deleuze e Félix Guattari. Especulando sobre a existência de dois aspectos na obra de Marília Garcia, a saber: cartografias afetivas e mapas sobrepostos, levantamos a hipótese de que sua obra pode ser vista como um "agenciamento maquínico" que se conecta com outros agenciamentos, ou seja, estabelecem conexôes que nâo se ligam a nenhum centro, a nenhum enraizamento, constituindo um platô. Nesse sentido, o sujeito lírico nâo se anula, nem se apaga, mas retorna como um "cartógrafo" que devora paisagens afetivamente, absorvendo matéria de varia procedência. O resultado é um mapa com múltiplas faces, múltiplas entradas e saídas, cujo olhar do sujeito lírico arranca a si mesmo da lógica binária ou pivotante, trabalhando na multiplicidade do jogo interioridade/exterioridade. Dessa forma, todo e qualquer ponto pode ser um centro, ao mesmo tempo em que pode năo o ser: tudo é passagem, mapa aberto, passageiro, "linhas de fuga".

Palavras-chave: Inespecificidade; rizoma; poesia contemporânea; sujeito lírico; multiplicidades.

ABSTRACT: The purpose of this article is to make some considerations about Marília Garcia's poetry with the initial pretext of the rhizome idea of Gilles Deleuze and Félix Guattari. Speculating about the existence of two aspects in Marília Garcia's work, namely: affective cartographies and overlapping maps, we raised the hypothesis that her work can be seen as a "machining agency" that connects with other agencies, that is, connections that they are not linked to any center, to any rooting, constituting a plateau. In this sense, the lyrical subject does not cancel out nor erase himself, but returns as a "cartographer" who devours landscapes affectionately, absorbing matter

Graduaçăo em Letras pela Universidade Estadual de Mato Grosso do Sul (2008), Mestrado em Literatura e Práticas Culturais pela Universidade Federal da Grande Dourados (2011) e Doutorado em Estudos Literários pelo Programa de Pós-Graduaçâo em Literatura e Linguística da Universidade Federal de Goiás (2019). Atualmente é professor colaborador na Universidade Estadual de Mato Grosso do Sul, Unidade de Campo Grande.E-mail:rosicleycoimbra@yahoo.com.br 
of varying origin. The result is a map with multiple faces, multiple inputs and outputs whose the lyrical subject's look seeks to pull himself out of the binary or pivotal logic, working on the multiplicity of the interior/exterior game. In this way, each and every point can be a center, at the same time that it may not be: everything is a passage, an open map, a passenger, "escape lines".

Keywords: Non-specificity; rhizome; contemporary poetry; lyrical subject; multiplicities.

\author{
ao escrever é possível pensar \\ em termos geográficos: \\ a gente constrói uma cartografia \\ e pouco a pouco vai desenhando e \\ descrevendo linhas \\ formas curvas montanhas acidentes \\ caminhos e superfícies \\ Marília Garcia
}

De imediato, a leitura dos poemas de Marília Garcia nos causa algumas inquietaçóes. Em linhas mais gerais, poderíamos conjeturar que elas se apresentam sob duas formas: como desconforto e como estranhamento. A primeira parece advir do choque entre as expectativas do leitor e o "conteúdo" dos poemas. Talvez isso aconteça porque năo encontramos de início as caraterísticas tradicionalmente atribuídas ao "gênero lírico", como a de "uma voz central [que] exprime um estado de alma e o traduz por meio de oraçôes" ou a de que um poema trataria "essencialmente da expressâo de emoçôes e disposiçóes psíquicas" (ROSENFELD, 2011, p. 22). A tese de uma voz central, isto é, de um "eu lírico" que comandaria e agregaria toda expressâo poética, passa ao largo dos poemas da autora. Além disso, os temas dos poemas de Marília Garcia centram-se, na maioria das vezes, em questóes relacionadas ao próprio fazer poético e as fronteiras da poesia, o que nos permite especular, nesse caso, sobre uma metalinguagem que questiona a si mesma e seu alcance crítico (?).

Acrescentemos como mais um contraponto, o fato de o "sujeito lírico" demonstrar que toda subjetividade é flexível, movente e experimental, comprovando também que dizer "o eu" já năo tem uma importância tăo fundamental assim. Afinal, "o Eu nâo é senhor em sua própria casa", conforme afirmaçáo de Freud (2010, pp. 250-1). Nesse sentido, o sujeito lírico, persona famigerada na lírica moderna, apareceria "fora de si", sem "o controle de seus movimentos interiores", o que faz com que ele se projete também em direçăo ao exterior (COLLOT, 2004, p. 166). Ou, para intensificar ainda mais a polêmica que paira em torno dessa figura, podemos dizer junto com Dominque Combe que "o 'sujeito lírico' nâo existe", mas "se cria no e pelo poema, que tem valor performativo" (COMBE, 2010, p. 128), ou seja, a performance é o ato que faz o sujeito aparecer/existir. Em outras palavras, o sujeito precisa dar-se a ver em espetáculo para poder existir e o poema seria a performance ideal para isso.

Assim, a segunda forma de inquietaçâo recairia sobre a indagaçăo: "o que é isso?", espécie de traduçăo imediata do espanto diante do inclassificável. No entanto, se o 
leitor deter um pouco mais a atençăo poderá reconhecer nos poemas de Marília Garcia a presença de outros gêneros, como a prosa, a narrativa e o ensaio, compartilhando um espaço mediado, na maioria das vezes, pela dicçáo autobiográfica presente nos livros. Trata-se de uma heterogeneidade que corrói as fronteiras que poderiam "definir" o que é a poesia e deixa o leitor deslocado em relaçấo aos conceitos comumente empregados no campo da lírica. Temos dentro desse contexto um pouco daquilo que Josefina Ludmer chamou de "literaturas pós-autônomas", cujo atravessamento de fronteiras caracterizaria uma "posiçâo diaspórica" das literaturas do presente, marcadas por um dentro e um fora que borram os limites outrora definidos, "como se [esses textos] estivessem em êxodo" (LUDMER, 2010, p. 1). Também poderíamos dizer que estamos diante de um caso de "inespecificidade estética", ou melhor, de "frutos estranhos e inesperados, difíceis de serem categorizados e definidos", pois estăo carregados de "misturas e combinaçôes inesperadas" (GARRAMUN̄O, 2014, p. 11).

Em graus diferentes, essas questōes perpassam a obra de Marília Garcia. Enquanto algumas estâo inseridas como temática, contrabalançando-se com preocupaçôes que refletem escolhas e concepçôes de poesia, outras aparecem como tensôes, como é o caso do sujeito lírico, que surge como figura performática responsável pelo estabelecimento de um jogo entre o interior e o exterior. Nos poemas de Marília Garcia, "o eu” nâo se equilibra sobre nenhuma base fixa, mas se confunde com as vozes com as quais interage. Encontramos, de fato, um "eu", mas também achamos um "tu/você" e um "ele/ ela" que, às vezes, sáo identificados pela marca pronominal, ao passo que em outras denotam o puro vazio. Essa indecisăo alimenta um jogo tenso de impessoalidade, dando origem a um movimento que oscila entre interioridade e exterioridade. Para Florencia Garramuño, essa "tensăo constante entre a primeira, a segunda e a terceira pessoas verbais, entre observaçóes, declaraçōes e perguntas, [...] se constrói como diálogo e incorporaçăo de um sopro narrativo" (GARRAMUN̂N, 2016, p. 16). Seria este mais um motivo daquela sensaçăo de estranhamento? Essa "posiçâo impessoal" do sujeito lírico, que se movimenta entre um "eu" e um "outro", além de inseri-lo no poema, cria também um espaço para reflexăo constante sobre o fazer poético.

Em relaçâo ao aspecto exterior, isto é, ao mundo como qual esse sujeito interage, podemos afirmar que a poesia de Marília Garcia fala de lugares. De fato, há um aqui e um lá, um alhures e um nenhures. Entretanto, essas categorias espaciais sâo convertidas em enganos geográficos, em referência ao título de um dos livros de Marília Garcia. $O$ que queremos dizer com isso é que os lugares nâo situam o leitor em um mundo real, nâo sâo referenciais e nem pretendem ser. Temos um caso de geografia literária, cuja lógica ou referencialidade é a da criaçăo literária. Sob essa perspectiva, nenhuma coordenada parece levar a um centro, nenhuma passagem serve como acesso. Trata-se de um espaço construído pela escrita, e a localizaçăo está apenas no texto, năo podendo ser transferida para nenhum mapa conhecido no mundo real. Talvez a palavra mais adequada para nomear esses lugares seja paisagem. A paisagem construída pelo poema, nesse caso, é uma reaçâo causada pela sensaçâo daquele que olha. Diferindo um pouco da percepçăo, que é năo é passiva, mas organizada em estrutura que lhe dá forma e sentido, a paisagem "confere ao mundo um sentido que năo é mais subordinado a uma crença religiosa coletiva, mas, sim, o produto de uma experiência individual, sensorial e suscetível de uma elaboraçâo estética singular" (COLLOT, 2015, p. 18). 
Nesse sentido, podemos acrescentar, ainda, que a obra de Marília Garcia é cheia de "linhas de fuga", conforme tese de Gilles Deleuze e Félix Guattari (2011), ou seja, é uma obra que está sempre apontando para um fora, fazendo com que qualquer tentativa de agregar ou centralizar seja comprometida por essas linhas. Dentro desse contexto, sujeito e paisagem constituem-se como intensidades, formando "platôs", isto é, criando "uma regiâo contínua de intensidades, vibrando sobre ela mesma, e que se desenvolve evitando toda orientaçấo sobre um ponto culminante ou em direçăo a uma finalidade exterior" (DELEUZE e GUATTARI, 2011, p. 44). A imagem do platô sugere a inexistência de um centro agregador ou de hierarquias, mas também de planificaçăo e multiplicidades.

Tudo isso é agenciado por um gesto poético que năo pretende ser reuniâo, mas abertura: o poema năo se fecha, o sujeito lírico é cambiante, os espaços se dissolvem e nenhum mapa situa geograficamente. Cada poema "é uma linha que nunca se fecha" (GARCIA, 2017, p. 17), um mapa sobreposto que confunde ao invés de localizar. Por essas constataçōes, poderíamos afirmar que a obra de Marília Garcia possui as qualidades de um "rizoma", pois "conecta um ponto qualquer com outro ponto qualquer e cada um de seus traços năo remete necessariamente a traços de mesma natureza" (DELEUZE \& GUATTARI, 2011, p. 43). Trata-se, portanto, de uma obra a-centrada, carregada de multiplicidades, composta por linhas que se cruzam, mas sem delimitar um território específico.

O rizoma é a metáfora que Gilles Deleuze e Félix Guattari tomaram da botânica para propor um projeto de desconstruçăo da lógica binária e seu modelo arborescente. 0 rizoma seria uma estrutura que năo possui unidade nem centro, mas pontos que podem se desenvolver como ramificaçóes. Diferentemente da árvore e seu sistema de raízes, o rizoma se baseia na multiplicidade e "nâo é feito de unidades, mas de dimensôes, ou antes, de direçóes movediças". Por isso, ele "năo tem começo nem fim, mas sempre um meio pelo qual ele cresce e transborda" (DELEUZE \& GUATTARI, 2011, p. 43). Em síntese, o rizoma năo é fechado sobre si mesmo, mas aberto a experimentaçóes e conexôes que se fazem ao acaso - linhas de intensidades que escapam a qualquer forma de contençâo. Além disso, como os pontos do rizoma nâo sâo fixos, mas em constante deslocamento, isso permite que sejam formadas novas linhas de intensidades.

Os títulos dos livros de Marília Garcia, guardadas as devidas proporçōes, parecem remeter à ideia de movimento, que pode ser para fora de si ou para fora do espaço físico, como se encarnassem linhas de fuga. Săo eles: 20 poemas para o seu walkman (2007), Engano geográfico (2012), Um teste de resistores (2014), Paris nâo tem centro (2015), Câmera lenta (2017) e Parque das ruínas (2018). Quando se faz um breve inventário das imagens mais recorrentes nesses livros, encontramos "mapas", "cidades", "ônibus", "ruas", “pontes" “bares", "pessoas", "olhares" “sons", "ruídos", "silêncio". Sâo imagens que sugerem algumas relaçōes passageiras, transitórias e abertas. Podemos dizer, ainda, que sâo linhas de fuga, mas também linhas que migram de um livro para outro, estabelecendo conexōes.

Com base nessas primeiras impressōes, a proposta deste trabalho é esboçar/ensaiar algumas notas sobre a poesia de Marília Garcia, considerando a hipótese de obra rizomática perpassada por várias linhas de fuga. E ainda, a ideia de um sujeito lírico que sobrevive do jogo entre interioridade e exterioridade é válida para pensarmos a 
dinâmica dessa figura na obra da autora. Trata-se de um sujeito performático que náo possui um lugar fixo, mas que se encontra em deslocamento, aparecendo somente na relaçâo entre "eu" e "outro", ou seja, ele precisa náo apenas dar-se a ver para existir, mas precisa realizar uma açăo, daí o poema como performance. E mais, nesse jogo pendular entre interior/exterior, o sujeito cartografa espaços, isto é, constrói paisagens seguindo o fluxo de intensidades que o atravessa.

\section{II}

Em um primeiro momento, a obra de Marília Garcia encarnaria aquilo que Florencia Garramuño chamou de impropriedade da poesia contemporânea. Ao explorar formas variadas, a poesia constrói para si um lugar que seria melhor descrito como impróprio, afastando-se das definiçóes e conceitos usuais, ao mesmo tempo em que também questiona o lugar recém criado. A criaçăo desse lugar relaciona-se "com a elaboraçâo de um trabalho com o impessoal", definido "como um limiar entre o pessoal e o impessoal que faz da voz lírica um lugar impróprio" (GARRAMUÑO, 2016, p. 11). A impropriedade da poesia contemporânea permite refletir acerca da figura do sujeito lírico descartando a tese romântica da "dissoluçâo do eu", mas adotando a de um "novo impessoalismo", ideia segundo a qual "os sujeitos aparecem de modo insistente, ainda que despidos de toda interioridade" (GARRAMUÑO, 2016, p. 12).

Encontramos na tese da impropriedade o argumento de uma voz lírica que se volta para a exterioridade das situaçóes, relaçōes e experiências, transformando-se em ponto móvel que se desloca constantemente, atingindo, às vezes, o estágio da errância. Trata-se de um movimento que se exibe "como o ponto de tensăo de uma cartografia do espaço intervalar entre seres e coisas", o que significa que a voz lírica aparecerá nesse espaço intervalar que pode ser traduzido como "entre lugares, entre pessoas, entre coisas" (GARRAMUN̂O, 2016, p. 12).

Marília Garcia demonstra ter plenamente consciência disso e seu trabalho responde nâo apenas às suas inquietaçōes pessoais, mas também é resposta teórica de uma pesquisadora da poesia. Reflete-se em alguns de seus poemas as leituras do poeta Emmanuel Hocquard, sobre quem escreveu uma tese de doutorado e com quem sua obra estabelece vários diálogos, seja através das citaçōes diretas, das reflexóes ou das assimilaçôes temáticas. Entre as tarefas que o poeta francês propōe, Marília Garcia destacou a de "[c]artografar os espaços, sobretudo os espaços entre as coisas, sejam elas obstáculos, circunstâncias, memórias, palavras ou sons" (GARCIA, 2008, p. 239). (Parece que a pesquisadora se tornou uma discípula dileta do poeta francês, incorporando em sua obra algumas das sugestóes!). Mas encontramos também nas produçôes da autora, referências a outras teorias e experimentos acerca da poesia, reflexo de suas leituras enquanto pesquisadora e poeta. Deve-se frisar que a impessoalidade náo se refere à figura do poeta enquanto figura ontológica, mas ao sujeito lírico, persona desapossada de seu lugar outrora canonizado. A preocupaçáo da autora, nesse caso, gira em torno dos momentos e situaçōes em que o poema busca, através do olhar ou da escuta, o que poderia ser transformado em poesia. Atravessa toda obra da autora uma preocupaçăo com a poesia enquanto gênero, mas também enquanto busca. Captar ou capturar o tempo, mas também sua passagem, săo imperativos presentes em seus 
poemas. Isso fica evidenciado em "Parque das ruínas", no qual lemos: "e de repente algo aparece: / algo que já estava ali / mas ao ser lido com outros olhos / pode virar fantasma / algo que já estava ali / mas que precisa de um olhar de fora para se tornar / acontecimento extraordinário" (GARCIA, 2018, p. 38). A leitura/releitura de um poema ou de uma paisagem pode ser reveladora de sentidos ocultos - este é um dos focos da autora em seus poemas.

Ao retomarmos o ensaio de Florencia Garramuño, compreendemos que a impessoalidade da poesia contemporânea

teria mais a ver com um esvaziamento do lugar do sujeito para fazer dele um lugar hospitaleiro de uma experiência concebida para além do prisma da experiência individual. Trata-se, portanto, de uma voz imprópria, de uma voz que nâo assume a propriedade nem sobre si mesma nem sobre os lugares nem sobre os discursos que a habitam (GARRAMUÑo, 2016, p. 12, grifos nossos).

O sujeito lírico, nesse sentido, năo possui mais um lugar definido, fixo, mas um espaço lacunar e instável que procura preencher saindo de si, conforme a tese de Michel Collot. Mas podemos pensar também em um jogo que se estabelece entre experiência e vivência, conforme a dicotomia benjaminiana estabelecida entre Erfahrung e Erlebnis. Desapossado de uma experiência comunicável ou partilhável (Erfahrung), o sujeito possuiria apenas uma vivência individual (Erlebnis), precária e desinteressante. Essa constataçăo levaria o sujeito a lançar mâo do olhar (e da curiosidade) em direçáo à figura do "outro", reconhecendo que perdeu seu lugar central e gerador de experiências e que, por isso, necessita do "outro". Ao fazer do "outro" uma parte indispensável para si, o sujeito dá origem a um jogo entre interioridade e exterioridade, inserindo-se nessa passagem entre o "eu" e o "outro". Essa oscilaçăo é necessária para que ele, sujeito, exista. Daí a afirmaçâo de Tania Rivera sobre o sujeito ser o "efeito de um ato que se dá numa trajetória, num circuito que necessita do outro, o convoca e só com ele se completa" (RIVERA, 2013, p. 28). Essa estratégia é puramente performática, uma vez que nâo se fixa em nada concreto, pois é sempre passageira. A açăo de falar sobre o outro ou de tê-lo como horizonte seria uma forma de reconhecer-se como existente.

A tese de "impessoalidade" da poesia contemporânea revela o aspecto tensivo da obra de Marília Garcia, ou seja, a "tensăo de uma cartografia do espaço intervalar" onde a voz se inscreve, mas sem propriedade, ou melhor, sem autoridade. No poema "pelos grandes bulevares", do livro Câmera lenta, a especulaçăo sobre o "outro" parece ser o eixo revelador de um desencontro e também de incomunicabilidade. O sujeito lírico é apenas observador distante:

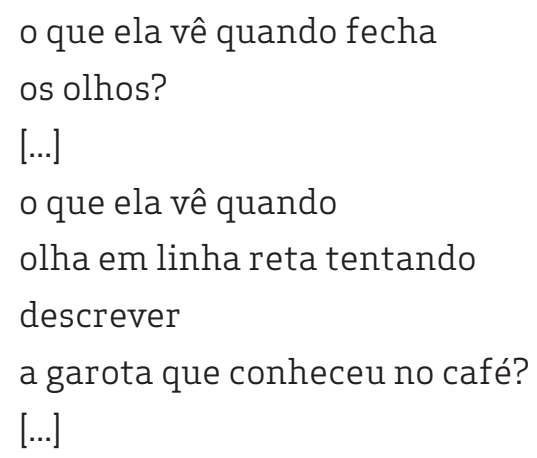




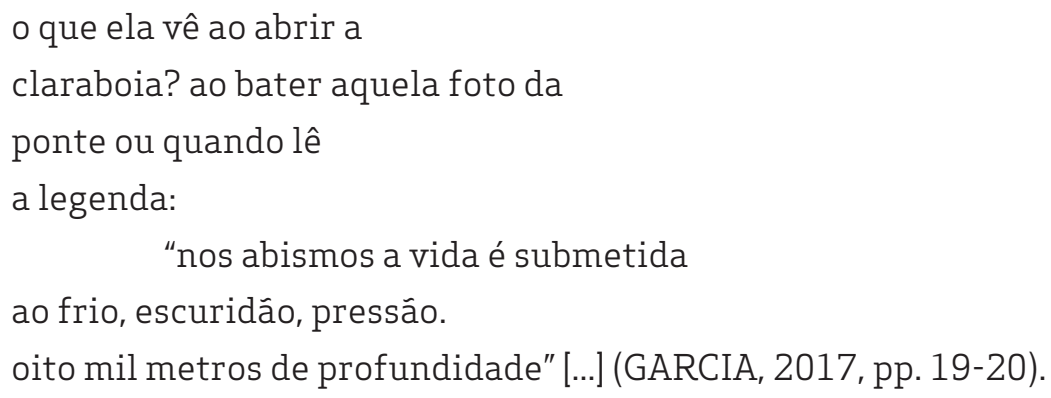

O que o "outro" vê ou pensa segue sendo um enigma. Encontramos nesses versos a tentativa do sujeito lírico de acessar uma vivência que náo é sua e tampouco se mostra acessível a ele. Nâo conseguindo acesso, o poema se desenvolve no espaço intervalar entre a curiosidade e a imaginaçăo, uma impossibilidade intensificada pelas interrogaçōes acerca do "outro". O olhar se transforma na única forma de apreensāo do "outro": olhar e imaginar passam a ser açôes dirigidas ao "outro", mas para falar de si. É nesse sentido que afirmamos que o sujeito só ganha sua existência ao falar do "outro": é na performance que ele ganha corpo, peso, importância. É nesse instante fugaz do olhar para o "outro" que ele existe. Ou, para sintetizar, podemos dizer com Tania Rivera que, a performance do sujeito do poema apenas "acentua um instante fugidio", pois ele é impedido de se fixar em um objeto (RIVERA, 2013, p. 30).

Em alguns poemas, intencionalmente, Marília Garcia joga com a ausência de pronomes para cavar ainda mais a distância entre o "eu" e o "outro". Em "Blind light", do livro Um teste de resistores, lemos: "eu gosto de omitir os pronomes em português / e criar essa confusáo / muitas vezes a gente năo sabe quem é o responsável pelas coisas" (GARCIA, 2014, p. 18). Essa omissăo proposital faz com que a flexăo verbal, além de criar uma ambiguidade, também deixe o discurso aberto. É o que acontece no poema "20 poemas para o seu walkman", do livro de mesmo nome: "depois descia as ruas / e queria ficar no carro trancado / segurando um livro" (GARCIA, 2007, p. 49). A ausência do pronome pessoal sugere um lugar vago que poderia ser ocupado tanto por um "eu" quanto por um "ele/ela". Por outro lado, a presença do pronome possessivo "seu" no título do poema sugere a presença do "outro". Nota-se, assim, um esforço do sujeito lírico em permanecer nesse entre, fazendo questăo de manter o jogo de ambivalências. Ao fazer esse jogo de distanciamento e proximidade entre a primeira, a segunda e a terceira pessoas, o sujeito lírico cria uma tensáo que alimenta o poema. E, ao mesmo tempo em que faz isso, também mantém o poema no meio do caminho.

Há, ainda, as ocasióes em que o sujeito lírico mostra estar consciente de que a voz é apenas uma questâo de performance. É quando demonstra que ela pode ser manipulada, deslocada, recortada e colada a outra situaçăo, como no poema "hola, spleen", que faz o papel de prólogo do livro Câmera lenta. Nesse poema, a figuraçấo do impessoal problematiza o desencontro do "eu" consigo mesmo. A performance do sujeito joga com um dentro e um fora, isto é, uma voz de antes e uma voz de agora:

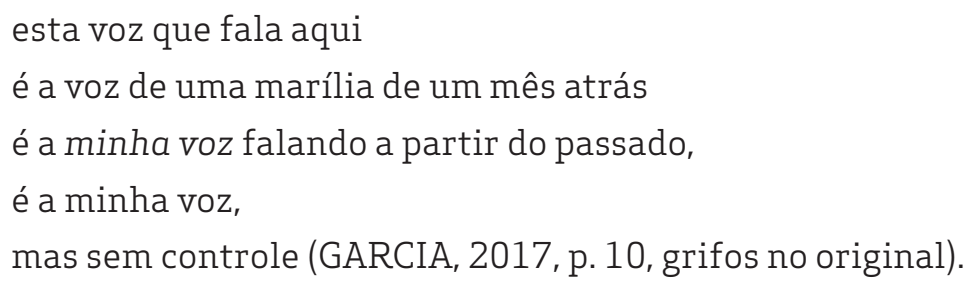


A voz de antes e a voz do agora pertencem ao mesmo sujeito? É uma resposta difícil de ser dada, posto que tudo é uma questăo de performance. O que se pode dizer com mais propriedade é que isso năo significa estar totalmente privado de voz. Mas podemos falar da posiçăo flexível e oscilante do sujeito lírico, que se desloca na performance. Assim, a voz de "uma marília garcia de um mês atrás" e a voz do aqui e agora fazem parte de uma performance que remete à uma outra performance. Reproduçâo da reproduçāo. Esse jogo impede que o "fingimento" poético se sustente, pois, antes que ele possa ter início, o próprio sujeito dilacera suas possibilidades.

A ideia de reproduçăo da voz ou de imagens é frequente em Marília Garcia. O recurso a dispositivos de reprodutibilidade apontam năo apenas para experimentaçóes, mas também para preocupaçōes formais e temáticas. Referências à walkman, gravaçóes, fotografias e filmes sâo incorporadas aos poemas e em suas reflexóes sobre poesia, estabelecendo conexóes. Podemos dizer que, em alguns momentos, o poema se desterritorializa para se aproximar desses dispositivos, buscando incorporar suas habilidades. Seria o caso de "Parque das ruínas", no qual os primeiros versos enunciam: "primeiro uma epígrafe em forma de imagem / [...] / a artista americana rose-lynn fisher / fez uma série de fotos [...]" (GARCIA, 2018, p. 11). Entre esses versos há uma foto do projeto da artista em questáo que vai sendo explorada pela autora. Também encontramos conexâo similar em outro poema, "estrelas descem à terra", de Câmera lenta, no qual o sujeito diz em sua performance: "esqueci de dizer que quando apresento / este texto ao vivo vou projetando / várias imagens enquanto leio / entăo / vocês podem pensar na imagem que quiserem" (GARCIA, 2017, p. 85).

O sujeito lírico também tenta mediar sua existência com o mundo através de imagens, ecos e ruídos. Dentro desse contexto, destaquemos os momentos em que o olhar cede lugar ao ouvir: "chega ao café e năo sobrou / ninguém só um rastro de eco" (GARCIA, 2007, p. 72); "ouço a voz em eco / no buraco do real" (GARCIA, 2017, p. 22); "às vezes ouço o mesmo ruído ao redor" (GARCIA, 2017, p. 37); "ouço o barulho da onda / e do barco" (GARCIA, 2017, p. 47); "os sons da fala / se intercalam com / os helicópteros" (GARCIA, 2017, p. 58). O mundo parece ter se tornado uma série desordenada de barulhos e ecos - helicópteros e hélices. Captá-los implicaria transformá-los em sinais de existência? Decodificá-los seria descobrir o que eles escondem? É entre ruídos, barulhos e sons que o sujeito se desloca. Caminha por ruas, parques e passagens; grava e fotografa buscando apreender nesse movimento o extraordinário que se esconde no ordinário: é na repetiçăo do cotidiano que ele busca capturar a passagem do tempo. Uma foto olhada várias vezes pode revelar, como por mágica, um detalhe especial: "às vezes a leitura é um jogo de escala: / é preciso se aproximar a ponto de perder o todo / mas outras vezes é preciso se afastar muito do texto" (GARCIA, 2018, p. 32).

No poema "uma equaçâo no hyde park", o deslocamento geográfico faz um jogo entre proximidade e distância, um indício claro de errância do sujeito: "está chovendo no / hyde park hoje / e estou do outro / lado do hemisfério". Mas também é sinal de desencontro: "o gps funcionou / e indicou o ponto de encontro / mas a mensagem / só chegou depois" (GARCIA, 2017, p. 21-22). A mensagem sempre chega tarde demais porque as referências se perderam, os mapas náo situam. Podemos antecipar que os mapas estăo sobrepostos, rasurados, náo remetem, portanto, a um lugar real. Resta ao sujeito a açâo de cartografar os espaços, isto é, traçar "linhas sinuosas, um mapa / feito à máo" (GARCIA, 2017, p. 19). A espera, o deslocamento ou o desencontro parecem ser 
motivos para esquecer de si e falar apenas do outro. Seguindo Michel Collot, é possível afirmar que esse sujeito desvia-se de si para poder se descobrir (COLLOT, 2004, p. 173). Ou, seguindo versos da própria Marília Garcia: "esta é uma forma de pensar em si / a partir do outro" (GARCIA, 2014, p. 19).

Voltando hipótese de que o sujeito lírico tenta mediar sua existência por meio de performances, parece até natural que ele levante o seguinte questionamento: " como fazer para essas palavras escritas / há um mês dizerem algo / sobre estar aqui / agora?" (GARCIA, 2017, p. 11, grifo no original), no poema "hola, spleen". Trata-se também de uma interrogaçấo que busca recuperar o instante em que ele, sujeito, passa a existir, mas também busca recuperar o instante da poesia. $O$ gesto principal nesse momento caminha para a escuta: "fazer silêncio / e deixar a escuta aberta / para ouvir" (GARCIA, 2017, p. 11, grifos no original). Ouvir o que o poema escrito semanas antes pode "falar" sobre o agora, mas também ouvir o que os ruídos querem dizer. Assim, quem sabe, "pode ser que ouça / alguma mensagem / perdida no ar" (GARCIA, 2017, p. 13). A intençăo pela escuta é proposital e se enuncia como objetivo um pouco antes no mesmo poema: "de repente neste silêncio / acontecer de ouvir algo por detrás / dos ruídos das máquinas voadoras que / cruzam o céu" (GARCIA, 2017, p. 12, grifos no original).

Mas o que se poderia ouvir por detrás do barulho? Já se sabe que náo é possível ao sujeito ter uma voz própria. Mas também fica evidente que o lugar dessa voz pessoal que ele busca foi ocupado por barulhos: "som infernal / estrelas caindo do céu" (GARCIA, 2017, p. 12). Sendo assim, o que se quer escutar, afinal? Escutar, afirma Jean-Luc Nancy, "é dar ouvidos [...], é uma intensificaçăo e um cuidado, uma curiosidade ou uma inquietude", mas também quer dizer "compreender". Em outras palavras, escutar é perceber um som e, a partir disso, năo se contentar apenas com o sentido, mas, conforme propóe Nancy, ir além do sentido com uma busca que gire em torno de uma "ressonância fundamental" (NANCY, 2014, p. 16).

E o que seria essa busca pela "ressonância fundamental" em Marília Garcia? Escutar um som, um ruído, um barulho seria compreender um esboço contextual ou uma situaçăo, mesmo que de maneira precária. Se estamos falando de barulhos de máquinas, ruídos e vozes, a imagem que rapidamente se forma é a de um martelar incessante: "ao chegar me acompanha / o ruído dos frascos na bolsa. / a vida é repetiçâo [...]" (GARCIA, 2017, p. 53). Assim, uma ideia que se faz presente nas preocupaçôes do sujeito lírico é a da repetiçâo e a questăo que surge é: "um dispositivo que produz a repetiçâo / pode produzir novas formas de / percepçăo?" (GARCIA, 2014, p. 22). A repetiçăo de sua voz gravada pode produzir algo diferente? Uma fotografia tirada de um mesmo lugar em momentos diferentes pode revelar algo? O que a repetiçăo pode significar? De maneira geral, repetir é seguir o percurso do neurótico e ser cativo dele. Mas para sair dessa teia é preciso repetir ainda mais.

As imagens que se apresentam ao sujeito lírico săo sempre as mesmas e os barulhos, ruídos e vozes sâo, em um primeiro momento, incompreensíveis. Mas dentro do contexto proposto por Nancy, estar à escuta pode ser entendido como um estar atento "a um sentido presente para além do som" (NANCY, 2014, p. 16). É preciso deixar a escuta aberta. O sujeito da escuta recebe o som e sente que ele se propaga através de seu corpo. O entregar-se à escuta em Marília Garcia teria como objetivo captar "o infraordinário" ou ouvir o "ruído de fundo", conforme Georges Perec, de quem a autora buscou a ideia (2010, p. 179). Essa escuta é perpassada pela destruiçăo dos sentidos já construídos, ou 
melhor, uma desconstruçăo que visa construir novamente. Gerar o caos, "mergulhar de novo no 'primitivo caos' das sensaçôes para recriar um mundo que seja năo o cosmo fixo de nossas representaçóes e formulaçôes habituais, mas um caosmo vivo e vibrante" (COLLOT, 2015, p. 22).

Assim, o sujeito lírico em Marília Garcia exerce uma força que oscila entre duas formas de perceber o mundo: ver e ouvir. Para sermos mais exatos, essas duas maneiras de perceber a realidade sâo colocadas em tensăo. Ver implica em tentar apreender o infraordinário, para isso o sujeito fixa o olhar no próprio cotidiano, para exercitar a "capacidade de olhar para o cotidiano / e para os gestos mais simples como por exemplo / acordar abrir os olhos lentamente e ver" (GARCIA, 2018, p. 27, grifo no original). 0 olhar da câmera (lenta), objetivo, busca captar um lampejo que cintile por um segundo no cotidiano, enquanto isso, entra em conexăo com a escuta de um ruído de fundo.

\section{III}

Chegar ao caosmo, como pretende Michel Collot, implica atravessar antes o território da língua - palavra e linguagem - já bastante explorada. Diz ele: "é preciso ser poeta para transmitir pelas palavras o que escapa a toda significaçăo clara e distinta", reativar a "parte da linguagem que se apaga na comunicaçăo ordinária em proveito da significaçăo" (COLLOT, 2015, p. 22). É assim que outra linha de fuga pode ser percebida em Marília Garcia: a exploraçăo do território da poesia. Explorar esse território significa questionar os próprios dispositivos que compóem o poema e fazer dele um experimento. Significa também um movimento de desautomatizaçăo da percepçăo da linguagem e das imagens poéticas.

No poema "em loop, a fala do soldado", o mundo do sujeito resume-se a um estar preso em uma caixa preta que limita sua visăo a imagens repetitivas:

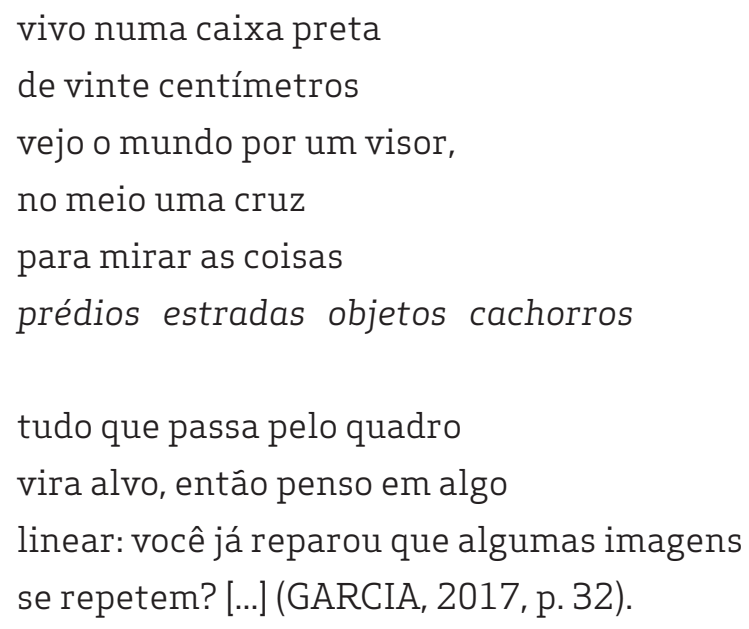

Viver (ou estar preso?) numa caixa preta e ver o mundo por uma abertura evoca, guardadas as devidas proporçôes, o mito da caverna de Platăo. Mas essa caixa preta também poderia ser um corpo, uma caixa de ressonância, que ressona/reage aos ruídos/estímulos que recebe. A imagem do loop trazida pelo título sugere repetiçâo, 
programaçâo, automatizaçăo: "eu năo sei como parar / a repetiçăo" (GARCIA, 2017, p. 32). Na linguagem da computaçấo, o loop tem como objetivo resolver um problema técnico através da repetiçâo contínua de uma açăo. Na música, é um recurso ligado a um arquivo sonoro por meio do qual se faz uso de trechos e fragmentos de outras músicas ou ruídos sonoros. Trata-se de um processo de reiteraçăo. Essas duas possibilidade do loop, no poema, sugerem uma lógica de repetiçăo, que por sua vez, pode ser aproximada da ideia de decalque, conforme Deleuze e Guattari. Seguindo os autores, podemos falar em um "decalque interminável de conceitos e de palavras bem situados, reproduçâo do mundo presente, passado ou por vir" (DELEUZE \& GUATTARI, 2011, p. 47). O decalque funciona como contençăo que, além de organizar, ordenar, estabilizar, limitar, também interrompe fluxos e quebra a multiplicidade. Em síntese, o decalque faz o movimento do corpo e seus fluxos cessarem, aprisionando-os: "vivo numa caixa preta".

O poema sugere que, estando dentro da caixa preta, deve-se acompanhar o movimento que se apresenta diante do olhar, privilegiando-se a repetiçăo: "você já reparou que algumas imagens / se repetem?". O pensamento deveria seguir a linearidade das imagens repetidas, como decalques? A percepçāo de quem está na caixa preta é estruturada e segue um código também pré-estabelecido. Sair da caixa preta significa passar por um processo de desterritorializaçâo que envolve trabalhar com as multiplicidades, isto é, com as linhas de fuga: "Fazer o mapa, năo o decalque" (DELEUZE \& GUATTARI, 2011, p. 30).

No entanto, o processo de sair da caixa preta também precisa incidir sobre a repetiçăo. Ou melhor: sobre um detalhe que possa servir como ponto de partida: "um pequeno detalhe destaca a forma de ver as coisas / e faz pensar em conexóes e relaçôes" (GARCIA, 2014, p. 12). A sugestăo parece ser olhar por uma perspectiva diferente, um olhar "de cima", como sugere o título do poema:

\author{
bem-vindo a este mapa \\ embora ele nâo traga \\ um acesso a \\ algo real (GARCIA, 2017, p. 61, grifos no original).
}

Esse olhar "de cima" seria um olhar sobre aquilo que nossa visăo naturalizou? O mapa oferecido pelo sujeito do poema náo é um mapa qualquer, mas é um mapa aberto, sobreposto, que nâo situa o "real". Retomando Deleuze e Guattari, podemos dizer que se trata de um mapa "conectável em todas as suas dimensōes, desmontável, reversível, suscetível de receber modificaçōes constantemente" (DELEUZE \& GUATTARI, 2011, p. 30). Portanto, năo se trata de um decalque, simples repetiçăo de passos através de uma trilha ou de um roteiro pré-traçado. Esse mapa, conforme imaginado por Deleuze e Guattari, "pode ser rasgado, revertido, adaptar-se a montagens de qualquer natureza, ser preparado por um indivíduo, um grupo, uma formaçăo social. Pode-se desenhá-lo numa parede, concebê-lo como obra de arte, construí-lo como uma açăo política ou como uma meditaçâo" (DELEUZE \& GUATTARI, 2011, p. 30). Em certo sentido, as palavras de Deleuze e Guattari reverberam nas consideraçóes sobre um poema de Emmanuel Hocquard em "Blind light": "ele traz à tona memórias da infância / e sobrepóe diversos mapas na narrativa / o mapa da infância / o mapa que percorre / o mapa da escrita que 
se sobrepóe às linhas do seu texto" (GARCIA, 2014, p. 29). Aparecem também nos questionamentos de "Uma partida com Hilary Kaplan", também de Um teste de resistores:

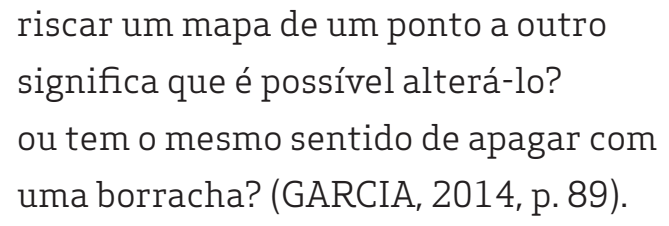

A possibilidade de alterar um mapa ao riscá-lo significa fazer conexóes com pontos improváveis, traçar rotas e roteiros diferentes a partir do que já está nele. Todo o poema é construído sobre interrogaçôes: seria um ensaio? Um experimento? Questâo de método? Ou simplesmente um teste de poesia, como no poema de Charles Bernstein que serviu de pretexto? Ensaiar, testar, arriscar, riscar o mapa. Riscar é, nesse contexto trazido por Marília Garcia, rasurar e traçar um percurso diferente sobre as mesmas linhas, mudando o sentido através de uma repetiçâo diferenciada: é pura performatividade. É na performance do risco sobre o mapa que o sujeito aparece, é na rasura que se estabelece o jogo entre o "eu" e o "outro". O mapa riscado é metáfora do poema, cuja equivalência está no gesto que traça as linhas sobre um poema, fazendo dele um outro poema.

Riscar se aproxima da "tremura", da "tremedeira", ambas lembrando o gesto inseguro da măo. Mas também está próximo do "terremoto", que pode riscar uma cidade do mapa e mudar completamente sua geografia original. Há ainda a possibilidade de rabiscar palavras espontaneamente, sem compromisso, como o rabiscar uma página em branco. Em todo caso, riscar evoca o movimento incerto, fora de ordem, errante, guiado apenas pela paixăo, pelo afeto. Surge daí uma inquietaçăo: "e se uma língua é desenhada / fora das linhas, / como conciliar o / inconciliável?" (GARCIA, 2017, p. 63, grifos no original). Essa pergunta poderia se transformar na principal linha de fuga da obra de Marília Garcia. O traçado fora das linhas da língua poética é a metáfora para seu fazer poético, isto é, como fazer poesia a partir da poesia, ou como fazer poesia falando de poesia? É um gesto necessário em tempos de impessoalidade e impropriedade da poesia.

Nesse sentido, o terremoto năo deixa de ser uma desterritorializaçăo. Podemos ligar essa tremura a uma outra forma de loop, nâo mais como repetiçáo mas sim como movimento e desestabilizaçáo. O loop apareceria agora como um movimento acrobático, helicoidal que desloca e quer "ver no escuro / [...] / sublinhando as palavras / em vermelho / e recortando os começos" (GARCIA, 2017, p. 67), como no poema "aqui começa o loop". É quando o traçado de um novo mapa começa, completamente "desmontável, conectável, reversível, modificável, com múltiplas entradas e saídas, com suas linhas de fuga", como querem Deleuze e Guattari (2011, p. 43). É a partir dos escombros de um terremoto que o processo de re-construçăo parece ter início. No entanto, é um processo que năo se conclui, pois segue o movimento das hélices, jogando tudo que está ao seu redor para fora: "uma hélice serve para deslocar" (GARCIA, 2017, p. 73) - puro deslocamento.

\section{IV}

O deslocamento causa um choque nas expectativas e direçōes que a leitura de um poema possa tomar. Mas é também uma forma de perceber outras e novas relaçôes possíveis na língua/linguagem: "conciliar o inconciliável". Temos aí o que poderíamos 
considerar como um segundo loop, que aparece como ruptura, linha de fuga. O loop como repetiçăo diferenciada, isto é, o fragmento repetido se desnaturaliza e se despoja de seu significado anterior. O deslocamento năo aparece mais como tema, mas como procedimento, processo e re-arranjo do processo. Essa ideia de deslocamento encontra na geografia algumas metáforas: mapa, cartografia, paisagens, montanhas, superfícies, platôs. Em "as estrelas descem à terra (do que falamos quando falamos de uma hélice)", poema-epílogo de Câmera lenta, a ideia de deslocamento ganha peso e a escrita do poema se constrói como uma reflexăo sobre isso:

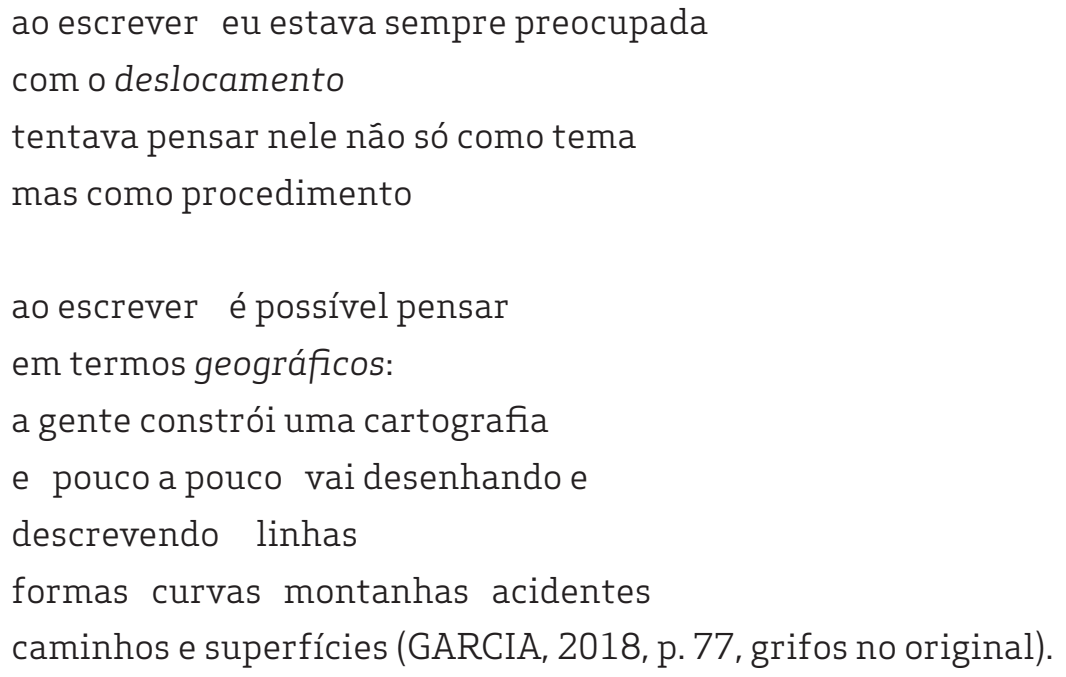

Construir ou desenhar uma cartografia com linhas, formas curvas, acidentes, enfim, sem nenhum protocolo que náo seja deixar-se guiar pelos afetos. O sujeito lírico transforma-se, assim, em cartógrafo, carregado por suas próprias intensidades. $\mathrm{Na}$ esteira de Deleuze e Guattari, Suely Rolnik afirma que o cartógrafo quer "mergulhar na geografia dos afetos e, ao mesmo tempo, inventar pontes para fazer sua travessia: pontos de ligaçăo" (ROLNIK, 2011, p. 66). A aventura cartográfica começa com a desconstruçáo de imagens prontas, repetitivas. É preciso sair da caixa preta e começar a questionar/ensaiar/testar. O sujeito lírico do poema em questăo está em busca das falas-aventuras, conceito da crítica portuguesa Silvina Rodrigues Lopes lida por Marília Garcia (GARCIA, 2017, p. 84). A aventura agora nâo é mais sair do lugar, mas trilhar percursos em "superfícies abertas":

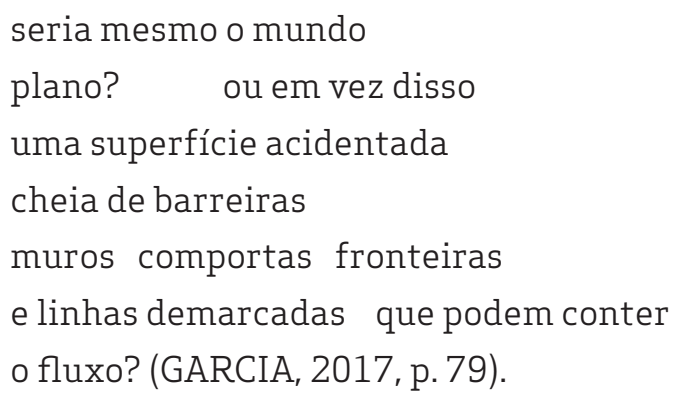

De um lado, liberar fluxos, romper fronteiras, linhas demarcadas, barreiras, enfim, desterritorializar. Do outro, mostrar a planificaçăo do mundo, mostrar que o poema é um platô, é anseio por reterritorializaçāo. Consciente de estar preso a imagens que 
se reptem, o sujeito procura por linhas de fuga, para isso inventa procedimentos. No entanto, o sujeito cartógrafo também se coloca em posiçăo tensa, pois fica entre o fluxo de suas intensidades e a representaçâo. Como para ele há somente intensidades, como afirma Suely Rolnik (2011, p. 67), pode acontecer delas escaparem. Ou seja: intensidades podem escapar do terreno de sua própria organizaçăo, desorientando sua cartografia, desestabilizando com isso a representaçáo, pois terăo seu fluxo estancado pelo sentido. O cartógrafo parece lutar o tempo todo contra o sentido e a tentaçấo de conferir unidade às suas intensidades.

Isso significa que o cartógrafo está sempre na iminência de cair no binarismo, no conceito, na arborescência. 0 "método", portanto, é nâo ter caminho traçado, já que nâo é possível definir um percurso, mas deixar-se levar pelo fluxo das intensidades, pelas falas-aventuras. Faz isso repetindo, retomando, refletindo sobre textos anteriores e insistindo sobre eles para que, nesse processo, algo novo apareça:

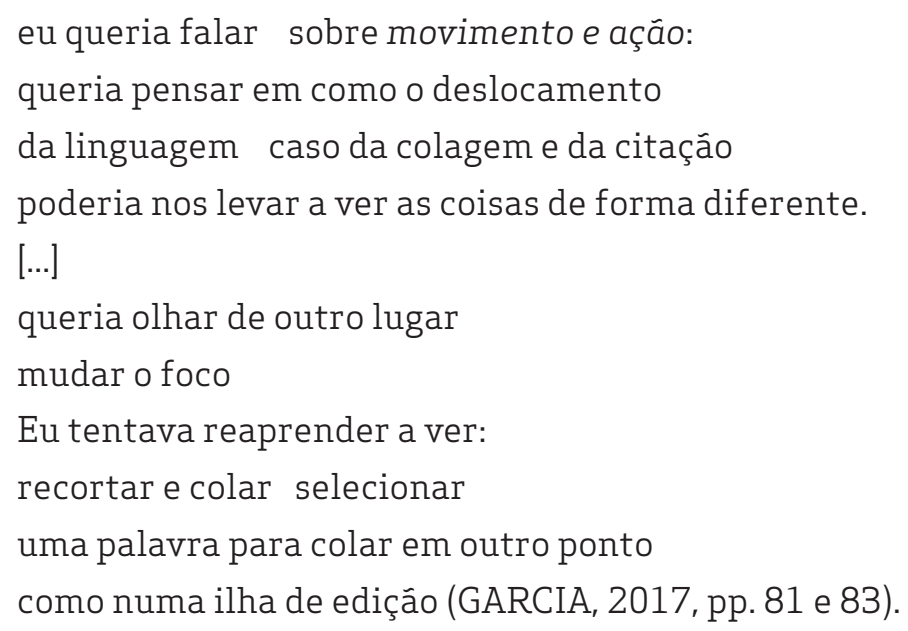

Deslocamento da linguagem, colagem e citaçâo: formas de quebrar hierarquias e criar novos movimentos e açōes ao ver as coisas de forma diferente. Deixar os afetos tomarem conta da seleçăo. Deixá-los decidir o quê recortar, o quê colar ou o quê citar. Sáo linhas de fuga que partem do olhar para as coisas, para os textos, selecionando-os afetivamente. Trata-se de um olhar que perscruta as coisas em seu ambiente usual, que busca por detalhes que falem algo diferente - é a busca do infraordinário. A partir daí cartografar, dar uma língua ao efeito causado por um detalhe, buscando recuperar um sentido primevo perdido nos ruídos e barulhos que soterraram a essência da poesia. Em síntese: encontramos nesse momento um agenciamento de elementos captados pelo olhar sob uma perspectiva que inverte/reverte fluxos, editando-os: selecionando "uma palavra para colar em outro ponto".

Nesse processo, a geografia é metáfora para representar o processo de desterritorializaçăo e territorializaçăo do poema, seguindo nâo mais escalas e valores numéricos, mas fluxos migratórios. Os espaços perdem-se enquanto categorias de localizaçâo geográfica e se transformam em espaços entre. As ruas năo levam para onde os mapas indicam e as passagens se transformam em labirintos. Tudo se transforma em engano:

qual o sentido da palavra

engano? engano é uma

fraude? ou significa 


$$
\begin{aligned}
& \text { errar de direçăo e ao chegar } \\
& \text { ver que tudo mudou de } \\
& \text { lugar? qual a relaçăo } \\
& \text { do sujeito com este tipo } \\
& \text { de erro um erro } \\
& \text { geográfico? (GARCIA, 2014, p. 91). }
\end{aligned}
$$

Qual seria o sentido do engano e do errar? "Errar" é caminhar sem rumo com um mapa nas máos, mas incapaz de se localizar. Para além do flerte com a "experiência do errar", percebemos também uma aproximaçâo com a figura errática do sujeito lírico moderno. "Errar é, simultaneamente, perda das referências conhecidas e aprendizagem do desconhecido, apavorante e apaixonante", diz Jeanne Marie Gagnebin na reflexăo sobre $O$ camponês de Paris, de Louis Aragon (GAGNEBIN, 2005, p. 156). A experiência do erro nos faz apalpar e conhecer as coisas pelo seu avesso. Entretanto em Marília Garcia, essa experiência nâo parte do abandono das coisas conhecidas. Pelo contrário, segue as linhas já traçadas, repetindo-as, insistentemente, para encontrar nelas o diferente - mesmo que seja preciso revirá-las pelo avesso. Trata-se de um processo de repetiçăo que visa mostrar um processo para descobrir nesse processo um outro processo.

Composto por um único poema, Engano geográfico é um dos títulos mais sugestivos da autora quando o tema é deslocamento. Ao que parece, todo o poema busca responder a uma pergunta: "onde fica o centro do mundo?" A resposta é postergada porque o mais importante náo é chegar ao centro, mas palmilhar um trajeto, isto é, sentir o caminho, a busca, o percurso:

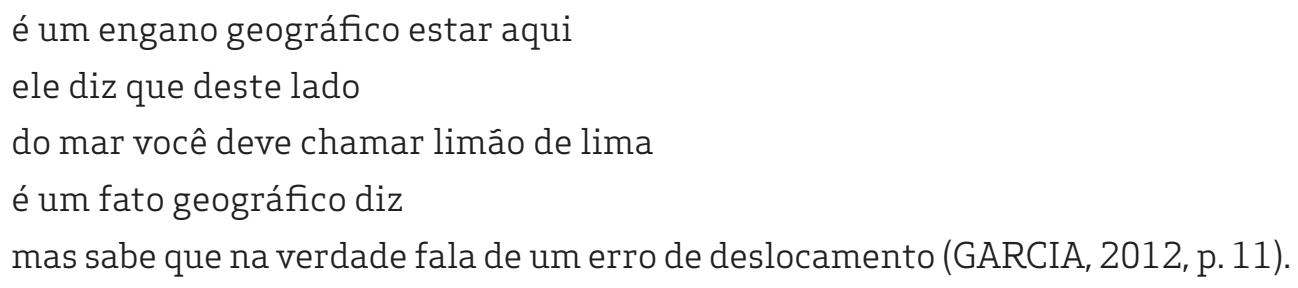

"Erro de deslocamento" sintetizaria, de alguma forma, uma oposiçâo à ideia de "engano geográfico", mas é apenas na aparência. Como um turista, o sujeito lírico busca se localizar nos mapas, mas "os mapas podem se sobrepor" (GARCIA, 2012, p. 11) e levá-lo a pontos que náo existem fisicamente: memória, afetos, sensaçōes. Mapas comuns năo levam ao ponto, năo levam ao centro do mundo - nâo há um centro, é a conclusăo a que chega o "ele" mencionado pelo sujeito. O deslocamento do sujeito lírico é de outra natureza, é metafórico. É um deslocamento que, antes de tudo, procura escapar ao poder fascista da língua, como diria Roland Barthes em sua Aula. É um percurso que se detém justamente na busca, mexendo com a língua. A partida e a chegada náo parecem importantes, pois nâo passam de decalques, isto é, repetiçóes:

$$
\begin{aligned}
& \text { o deslocamento de trem um erro } \\
& \text { seguir uma linha para tarbes } \\
& \text { seguir uma linha para toulouse } \\
& \text { seguir uma linha para Perpignan }
\end{aligned}
$$


a geometria euclidiana de planos ele diz

antes de entrar no trem (GARCIA, 2012, p. 19).

Năo se trata, portanto, de um deslocamento físico, mas de uma busca que atravessa o poema, procurando as linhas ocultas pelas linhas visíveis: "um trem pode esconder outro trem / como uma linha pode esconder outra linha" (GARCIA, 2014, p. 30). Um deslocamento leva a outro e assim vâo se multiplicando os caminhos, as passagens, os enganos. Esse deslocamento náo segue "a geometria euclidiana de planos", objetiva como a língua em uso, mas busca um percurso traçado no decorrer da viagem, e está sujeito ao fluxo das intensidades e dos afetos do sujeito viajante. $O$ acaso das ruas e dos caminhos pouco palmilhados parecem ser a abertura que se busca para deixar escapar o desejo:

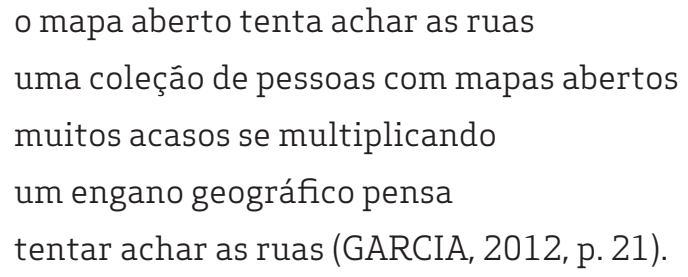

Caminha-se por ruas e passagens de um platô. O centro năo é localizável. Pessoas e mapas abertos: multiplicidades em movimento. $O$ sujeito aqui trabalha na exterioridade, pois é apenas acompanhante: é o "outro" quem viaja. Como companheiro de viagem, parece apenas querer alertar:

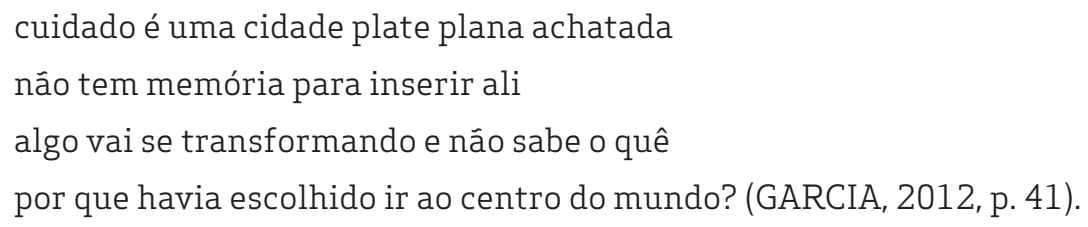

A cidade é vista como um platô, é plana, achatada e sem cume. A memória curta é rizoma; o contrário da memória longa, que é arborescente e genealógica. Em um platô, o centro pode ser em qualquer ponto. O lado de dentro pode ser o lado de fora, a entrada pode ser a saída. A linha do trem é repetiçăo e o destino a que ela leva já é conhecido nâo é o centro. O sujeito reproduz o questionamento do "ele": "o que foi fazer no centro do mundo se pergunta" (GARCIA, 2012, p. 45), para em seguida descobrir:

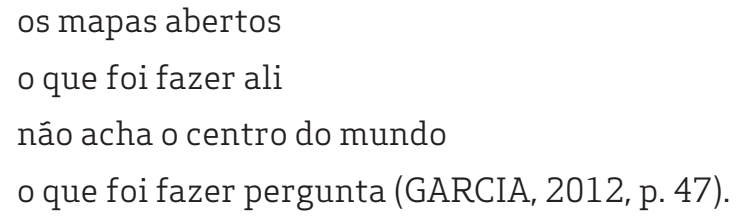

Nâo há centro do mundo, logo, “o que foi fazer ali” sumariza a ideia de engano, de erro. Engano geográfico é a metáfora para o olhar que vê somente imagens passando pela janela enquanto o trem segue em linha reta (uma possível analogia com a caixa preta?). A sobreposiçáo de mapas revela que náo há centro, mas caminhos vários, labirintos, pontos que levam a outros pontos, linhas que se cruzam. Uma coleçáo de mapas e passagens que levam a outras passagens. Nesse caminhar errante, "o sujeito fora de si" traça o rabisco sobre o mapa, rasura suas linhas. É nesse gesto performático que se 
coloca no mapa como sujeito, garantindo uma presença precária. E mais, o plano da viagem é desviado. Náo se trata de uma viagem com partida e chegada, mas de uma viagem que parte do meio e segue nesse meio-caminho. Ressona em Engano geográfico as palavras de Deleuze e Guattari: "buscar um começo, ou um fundamento, implicam uma falsa concepçăo da viagem e do movimento" (DELEUZE \& GUATTARI, 2011, p. 49).

\title{
V
}

O deslocamento leva a pensar em uma outra linha de fuga na poesia de Marília Garcia: a simultaneidade. Instante em que o fazer e o ser andam juntos, mas sem que haja harmonia perpétua nessa caminhada. Isso significa que ao mesmo tempo em que o poema é escrito, ele questiona a si mesmo e coloca entre parêntese a(s) definiçâo(ôes) de poesia ou de gênero lírico mais tradicional. Para ser poema, o poema precisa se desconstruir antes, mas só pode fazer isso durante sua própria construçấo. O momento da escrita é também o momento da reflexáo, como em "O poema no tudo de ensaio", de Parque das ruínas:

\author{
quando comecei a escrever esse texto \\ para uma jornada sobre o ensaio na unifesp \\ eu queria falar de um poema do escritor americano \\ charles bernstein o poema era um teste \\ chamado "um teste de poesia" \\ eu queria começar falando \\ daquele teste mas acabei sendo levada a falar de \\ outro teste (GARCIA, 2018, p. 59).
}

Podemos dizer que, aqui, o poema vai se construindo como um ensaio, que se desenvolverá através do exercício de outras formas, como a prosa e a narrativa. Ao mesmo tempo, o poema passa por um experimento - como se fossem testados pesos distintos para um equilíbrio adequado - que testa seus limites - até onde vai a poesia? A poesia configura-se, dessa maneira, como uma forma movente que fica entre o ser poema e o ser ensaio. Coloca-se aqui também a questăo dos limites da poesia, problematizado pelo próprio poema ao questionar a si mesmo como poema. É muito comum em alguns poemas de Marília Garcia "comentários" sobre a construçăo de seus poemas, fazendo, inclusive, referência a eles. É o momento em que o poema busca se conectar com o discurso científico, usado como "método" ("caminho"), para chegar a um parâmetro ou a uma ideia de poesia: "estou tentando pesar um poema com os parâmetros do ensaio", diz um dos versos (GARCIA, 2018, p. 71).

A poesia se transforma, para Marília Garcia, em experimento, ou melhor, em oportunidade para "testar as palavras de descrever experimentando / de descobrir algo escrevendo: descobrir com a măo / entrar na escrita ao modo da traduçăo" (GARCIA, 2018, p. 62). Experimentar, testar, ensaiar e traduzir săo palavras-chave em Marília Garcia que podem ser sintetizadas nesse "descobrir com a măo", gesto performático que objetiva encontrar o diferente no mesmo. Essa dicçăo ensaística está em seus poemas como marca, mas também como inquietaçấo: "as regras para o teste nâo estavam dadas de antemâo: / era preciso ensaiar" (GARCIA, 2018, p. 63). A poesia é, nesse sentido, 
desejo de ultrapassagem dos parâmetros dados, é busca de outras linhas de conexôes, como a fotografia e o cinema - é teste!

Exemplo similar pode ser encontrado em "Blind light", no qual uma das preocupaçóes do sujeito é em relaçăo a construçăo do poema: qual é o momento ideal do "corte" no poema? Reconhecendo em seguida que é muito difícil falar de poesia e precisar o uso de recursos:

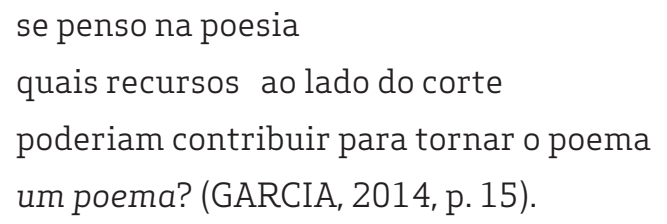

Os dois recursos sugeridos pelo poema nesse excerto sâo o enjambement e a cesura. Segundo Giorgio Agamben, eles seriam possíveis somente na poesia, sendo, portanto, seus denominadores comuns. De alguma forma, o excerto evoca aquilo que Pierre Alferi chamou de "assombraçăo da prosa" (2013, p. 426), isto é, por mais que se negue à prosa um lugar na poesia, ela está em seu início, daí essa preocupaçáo em se afastar dela ao conferir ritmo ao poema por meio dos expedientes do enjambement e da cesura. É nesse sentido que o poema se coloca, aqui, como a linguagem falando da linguagem ou, do poema falando do próprio fazer poético. Essa consciência também aparece no mesmo poema, quando o próprio Giorgio Agamben é citado textualmente: "posso deslocar a leitura de giorgio agamben / (ou cortar) / e repetir para pensar na poesia / corte e repetiçăo" (GARCIA, 2014, p. 15, grifos no original). Para além da metalinguagem, que apenas coloca a linguagem como tema ou assunto, o que parece mais evidente no em questăo é a "resistência da poesia", conforme a tese de Jean-Luc Nancy: "[o] sentido de 'poesia' é um sentido sempre por fazer", pois "por essência, [a poesia é] mais e outra coisa que a própria poesia". Assim, segundo Nancy, podemos encontrar poesia "onde sequer há poesia", onde há "recusa da poesia" ou seja, onde a "poesia nâo coincide consigo mesma" (NANCY, 2013, pp. 416-7).

Nesse caminho, rumo à "năo coincidência da poesia", que faz com que ela seja o que é, "impropriedade substancial" (NANCY, 2013, p. 417), os poemas de Marília Garcia flertam com o ensaio, forma semovente, que testa limites e conceitos, mas sem defini-los. Definir, nesse caso, seria aprisionar a poesia e forçar seu fechamento, considerando-se, nesse caso, a etimologia da palavra - de-finis: "limitar", "finalizar". A poesia é um năo-lugar que fica "entre" todos os lugares, enquanto o "poema é a coisa feita do próprio fazer" (NANCY, 2013, p. 420). Ao se fazer, a poesia nega-se e isso também significa que ela também "nega que o acesso ao sentido possa ser confundido com um modo qualquer de expressáo ou de figuraçăo" (NANCY, 2013, p. 417). E ainda, a poesia năo permite "identificar-se com qualquer gênero ou modo poético" (NANCY, 2013, p. 420). Assim, antes de mais nada, importa observar que a poesia de Marília Garcia se concentra no fazer do poema, que também se traduz em resistência contra sua definiçâo. Sua poesia seria um tubo de ensaio, um teste de resistência, ou "uma forma de resistência" (GARCIA, 2014, p. 118) cujo sentido vai se construindo no próprio fazer, mas nunca chega ao fim: "hoje quando fecho os olhos / penso naquela linha que nâo fecha" (GARCIA, 2017, p. 18). Essa linha que nâo se fecha é o poema! 
Teste, ensaio: experimento, afeto. Uma equaçăo estranha, mas que em Marília Garcia parece fazer sentido. Afinal, qual parâmetro para dizer que um texto é um poema? Ou: "o que faz um poema ser um poema?", pergunta o verso-citaçăo de Charles Bernstein incorporado pela autora às suas inquietaçōes (GARCIA, 2018, p. 70). É assim que Marília Garcia testa, ensaia, experimenta e seleciona. Nesse processo, năo há parâmetro claro, nem mapa seguro - "Le pays n'est pas la carte" (GARCIA, 2007, p. 31). Podemos afirmar que o que há sâo cartografias afetivas e mapas sobrepostos.

O cartógrafo é aquele que escolhe, que seleciona o que o afetou, que causou nele uma afecçăo (affectio), recorrendo mais uma vez a Gilles Deleuze. Nesse sentido, conforme o filósofo, affectio năo é somente o "efeito instantâneo de um corpo sobre o meu", mas também o "efeito sobre minha própria duraçăo, prazer ou dor, alegria ou tristeza" (DELEUZE, 2011, p. 178). O afeto é um pensamento ainda năo representado, confuso, que causa movimentos e faz o corpo vibrar. Essa vibraçăo/inquietaçăo é o efeito causado pelo afeto, é a afecçăo. Assim, encontramos na poesia de Marília Garcia, para além do olhar cartográfico, que constrói e ao mesmo tempo desmancha, um trabalho que é consequência de "um discurso-percurso-corpo pontuado por citaçóes afetivas ou, em outras palavras, por momentos de encontros discursivos" (DI LEONE, 2015, p. 132). Encontros da poesia com outros discursos ou encontros da autora com outros textos, ou ainda, encontros do sujeito lírico com outros lugares-discursos.

É nesse sentido que a possibilidade de um sujeito lírico rizomático na obra de Marília Garcia năo é totalmente descartável nesse contexto. Sob essa perspectiva, é possível ver sua obra como um "agenciamento maquínico" (DELEUZE \& GUATTARI, 2011) que se conecta com outros agenciamentos. Em síntese, săo conexōes que náo se ligam a nenhum centro, que náo possuem nenhum enraizamento, mas que se constituem como um platô, sempre no meio, sem início nem fim. Nesse aspecto, o sujeito lírico rizomático é sem fixidez, por isso age cartografando vozes e paisagens, devorando-as afetivamente, absorvendo matéria de varia procedência, seguindo linhas de fuga. O resultado é uma cartografia com múltiplas faces, múltiplas entradas e saídas - um mapa aberto, sem centro, composto várias linhas e várias passagens.

O olhar do sujeito lírico rizomático arranca a si mesmo da lógica binária ou pivotante, trabalhando na multiplicidade. Assim, todo e qualquer ponto pode ser um centro, ao mesmo tempo em que pode náo sê-lo. Tudo é passagem, um mapa desmontável: "o mundo já năo seria redondo / mas uma superfície plana / cheia de buracos" (GARCIA, 2017, p. 55) e "o ponto de encontro é cada vez mais distante" (GARCIA, 2007, p. 20). Nâo há nenhum percurso previamente elaborado, náo há roteiros, mas um mapa que se constrói enquanto o sujeito olha e recolhe: "sobreposiçâo de mapas afetivos" (GARCIA, 2014, p. 30).

O poema precisa lidar com lascas o tempo todo, partículas de afetos que escapam à organicidade, que fogem à hierarquizaçấo. Essas partículas constituem as linhas de fuga que quebram as estruturas que propóem sentidos e significados fixos. O poema nunca chega ao seu fim, mas permanece como um estar sempre no meio do caminho. Trata-se de um deslocamento constante e necessário para continuar a ser intensidade. 0 poema pronto é apenas "uma forma de leitura das coisas" e a possibilidade de um diálogo continuar, mesmo após seu término, nâo está descartada: "quando escrevo um poema / procuro uma espécie de abertura de repetiçấo de diálogo" (GARCIA, 2014, pp. 30-31). 
Alguns poemas de Marília Garcia săo, dessa forma, retomados, reescritos, redesenhados. Em outros casos, o acréscimo de um "prólogo" modifica a percepçáo da leitura anterior. É o caso de "Blind light", cujo início narra a situaçăo inicial do poema, que foi "originalmente" apresentado em uma performance: "depois mudei pequenas coisas no texto / inserindo comentários como este aqui / e incorporando a conversa que tivemos no dia" (GARCIA, 2014, p. 13). Há ainda o exemplo de "tem país na paisagem (versăo compacta)", de Câmera lenta, que se desdobra no poema "Parque das ruínas", do livro de mesmo nome. Náo seriam estas, também, formas de deslocamento, isto é, o gesto performático do sujeito que rasura o próprio texto é um deslocamento?

\section{VI}

Deslocar mas nunca atingir o centro. A estratégia é causar enganos geográficos. Composto por um único poema, o livro Paris não tem centro também evoca a imagem do deslocamento e do erro. Nele, o sujeito lírico torna-se um caminhante, errático e temporário, transformando as famosas passagens parisienses em espaço de perda e de ausência:

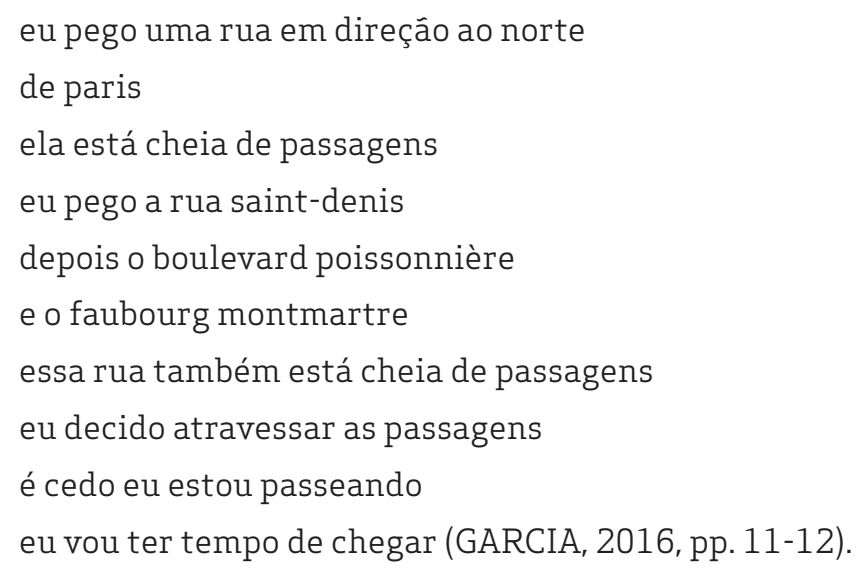

$O$ ato de caminhar pelas passagens pode ser lido como um gesto performático: 0 sujeito quer dar-se em espetáculo, isto é, quer ser percebido como sujeito. No entanto, conforme consideraçăo de Tania Rivera, o gesto implica a presença do corpo, mas também aponta para fora dele, para um outro corpo que deseja cooptá-lo (RIVERA, 2013, p. 44). Assim, ao invés de se encontrar, o sujeito perde-se ainda mais, sendo estranhado pelo próprio espaço que se transforma no corpo que tenta aliciá-lo - corpo contra corpo. Nesse movimento, o centro deixa de existir para se transformar em uma série de passagens desconexas, labirínticas - momento de desterritorializaçăo:

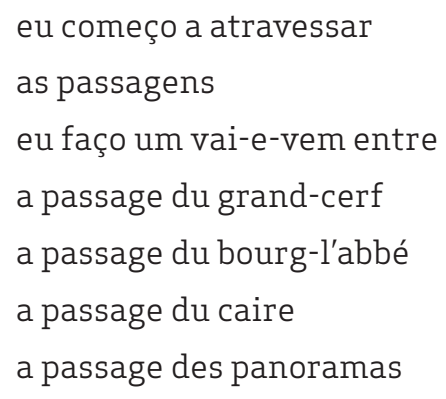




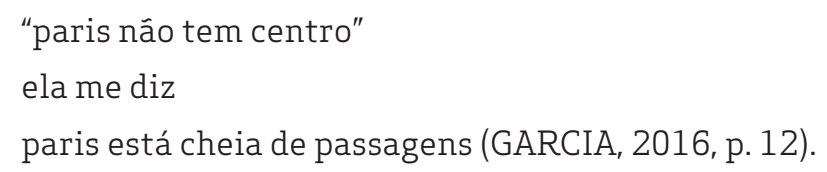

O gesto de caminhar pelas passagens tem algo de similar do gesto de rabiscar. 0 sujeito desenha mapas nessa caminhada errante pelas passagens, mapas sobrepostos que năo indicam centro, mas sugerem a forma de existência do próprio poema como passagem. Paris nâo tem centro parece encarnar a metáfora do labirinto, cujo centro e saída sáo sempre adiados. Sair dele somente com a ajuda do "outro". Nesse espaço, o "eu" sem o "outro" é miragem. Ir ao encontro do "outro" significa perder-se antes:

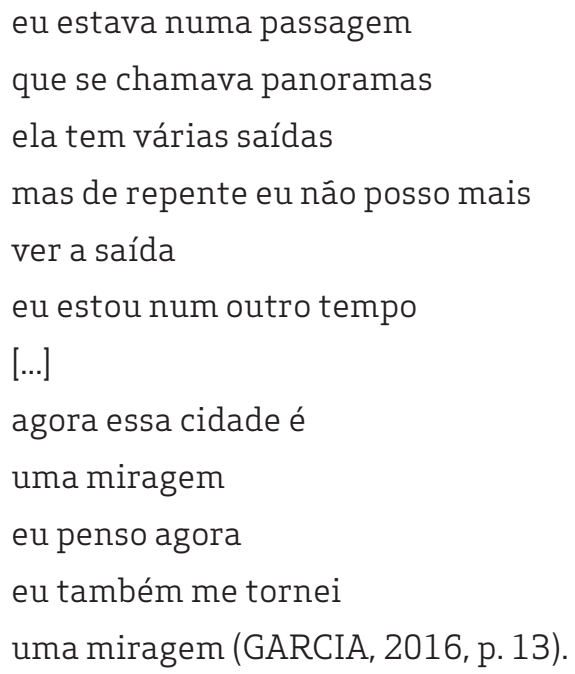

Como se percebe, a presença do outro é crucial dentro desse contexto, pois serve para lançar o olhar que assegura existência ao sujeito. Mas o espaço é de ausência e coordenadas: assim também é o sujeito que caminha por ele. $\mathrm{O}$ espaço é dissolvido e perde sua fixidez e năo serve como referência, isto é, năo dá conta de sustentar uma imagem do sujeito. $O$ espaço transforma-se em paisagem e, como tal, é mais complexa e compósita, pois é uma imagem "elaborada a partir do ponto de vista de um sujeito" (COLLOT, 2012, p. 24). Nesse estágio, sujeito e paisagem se tornam inseparáveis, confundindo-se. A insistência na repetiçăo do pronome "eu" nâo é suficiente para fazer o sujeito re-encontrar-se. Tornado miragem, esse "eu" passeia sem rumo, erra pelas famosas passagens parisienses, tornado ele também apenas uma passagem. Perdido em um espaço que náo consegue mais perceber como referencial, o sujeito torna-se objeto:

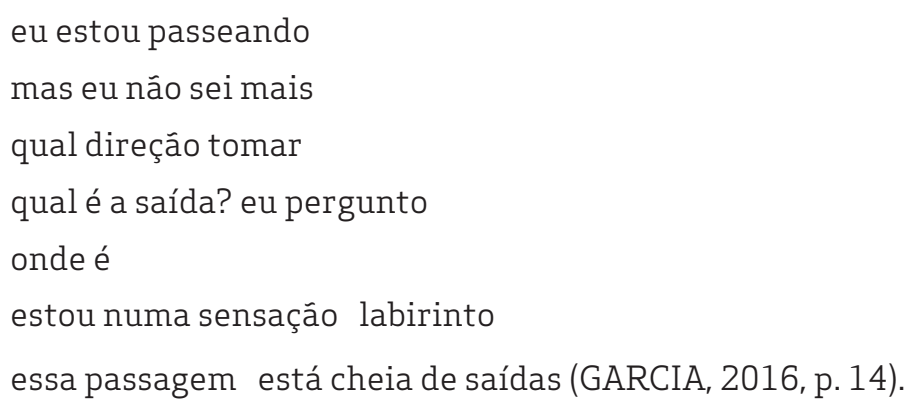

As saídas săo várias, multiplicidades em movimento, fluxos ininterruptos. Daí a "sensaçâo de labirinto" que pode ser uma traduçâo do medo de estar sozinho e 
perceber-se esvaziado. Mas também pode ser a imagem da multiplicidade de entradas e saídas e conexôes. Parece ser ainda preciso dar-se ao olhar do "outro", já que o olhar das passagens náo o recompóe como sujeito, mas o transforma em objeto. A performance só se justifica quando é direcionada a alguém. Perder-se do olhar do "outro" é perder-se como sujeito.

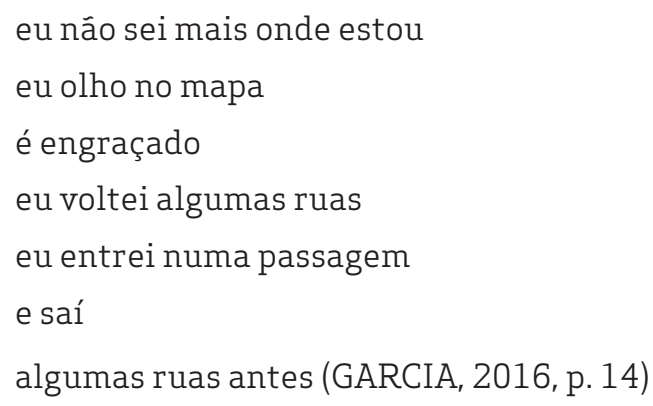

Quantas vezes é preciso dizer "eu" para dizer "o eu"? Dizer "o eu" năo faz sentido quando o sujeito está desbancado de seu lugar. Ele só existe como efeito e tal só acontece na presença do "outro". O excerto parece sugerir, pela repetiçăo insistente do pronome "eu", a angústia de năo se saber existindo. Paris năo tem centro pode ser lido como um poema que fala de um encontro que năo se concretiza, nâo somente pela dissoluçăo do espaço, mas também pela constataçăo do sujeito de que sua identidade é pura laceraçâo. Da mesma forma, o espaço também "deve ser inventado, criado em ato na flutuante, movente e estilhaçada medida do sujeito" (RIVERA, 2013, p. 42). Em igual medida, espaço e sujeito se igualam como categorias, pois sâo incapazes de se manterem fixos. O primeiro, por se converter em paisagem transformada pelo olhar daquele que a cartografou, pura percepçăo e desejo. Enquanto o segundo, encena sua existência através da ausência e da presença do "outro".

E suma, Paris nâo tem centro pode ser lido como um poema que ensaia, ou melhor, que executa uma performance sobre duas realidades que se cruzam: a do espaço, que se desagrega e se expande, e a do sujeito, dilacerado e errante em um mundo disperso. Assim, ressona nessas palavras, a fala do poeta Octavio Paz, quando afirmou que, em um "universo que se desmancha e se separa de si mesmo, totalidade que só é pensável como ausência ou coleçâo de fragmentos heterogêneos, o eu também se desagrega" (PAZ, 2012, p. 266). Dentro desse argumento está contido a imagem do mundo cujo centro também se deslocou e junto toda coesăo possível. Mas essa dispersâo năo significa pluralidade, e sim repetiçăo, "proliferaçăo do idêntico", nas palavras de Octavio Paz. Há, nesse contexto, a representaçăo de pelo menos dois problemas que o poeta moderno encara: do mundo sem uma imagem definida e da crise dos significados.

\section{VII}

Estas breves notas poderiam ser encerradas apenas com a imagem abaixo, pois representaria um esquema pictórico da obra de Marília Garcia. O texto aqui proposto foi mais um ensaio, năo se pretendeu esgotar nenhuma das possibilidades de leitura da poesia da autora. $O$ que significa que a multiplicidade náo quer ser unidade, que o rizoma é linha, náo círculo: "Faça a linha e nunca o ponto! A velocidade transforma o 
ponto em linha! Seja rápido, mesmo parado! Linha de chance, jogo de cintura, linha de fuga" (DELEUZE \& GUATTARI, 2011, p. 48).

\section{Figura 1: Wall drawing 118}

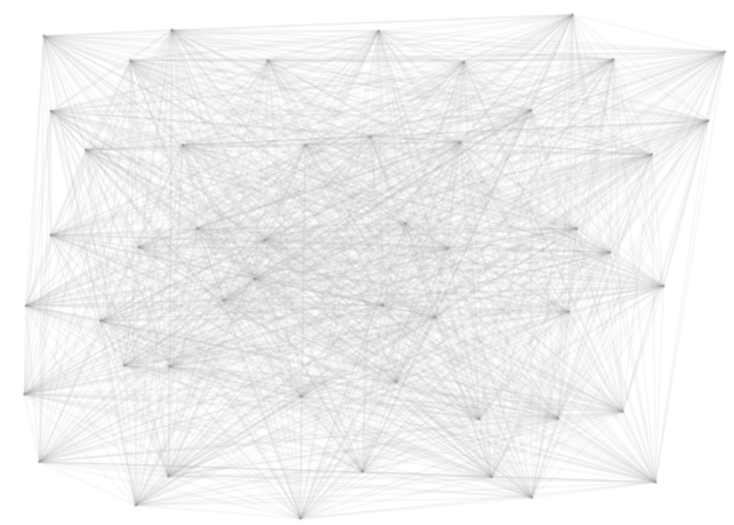

Fonte: Sol LeWitt

O trabalho de Sol LeWitt, Wall drawing $118,{ }^{2}$ citado pela autora em Paris nâo tem centro, parece encarnar a ideia de multiplicidade e de mapa sobreposto. Ele encarna também a ideia de participaçáo do outro em sua composiçáo, como se ele só se tornasse o que é porque outras mâos que náo a do artista agiram:

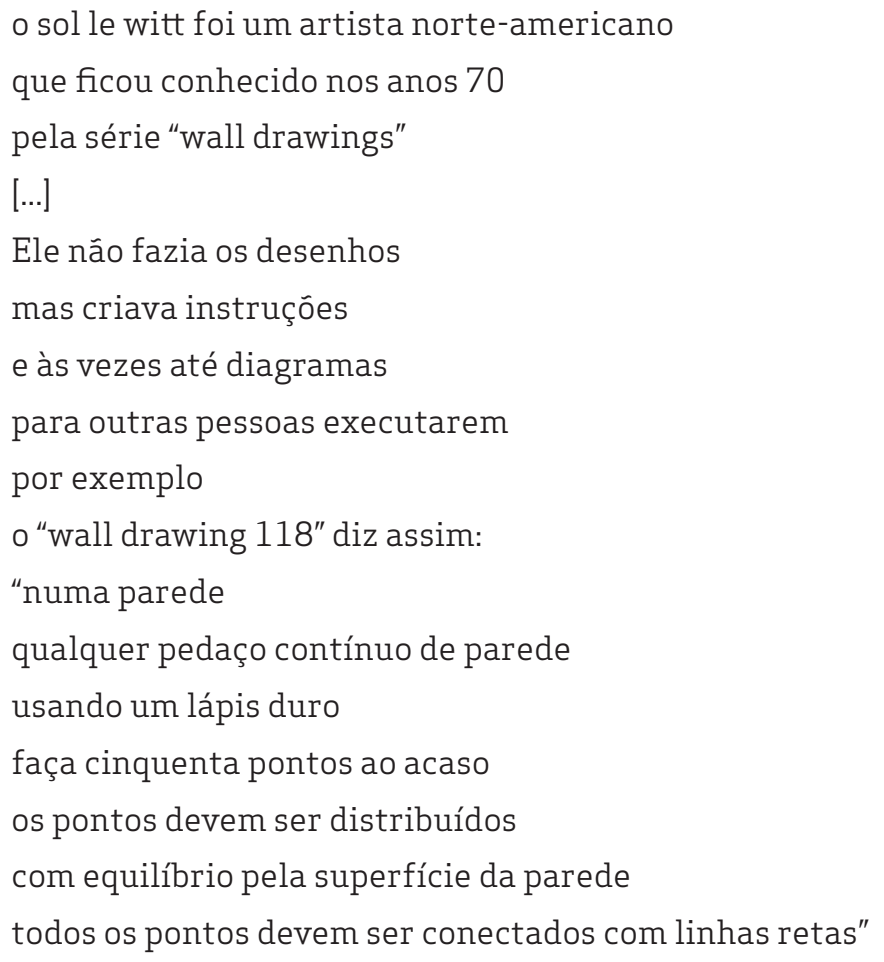

2 Disponível em: http://lepaysnestpaslacarte.blogspot.com/search/label/sol\%20lewitt. Consultado em: 23/05/2020. 


\author{
alguém executava as instruçóes para ele \\ e cada desenho \\ mesmo seguindo à risca o modo de usar \\ poderia ser diferente \\ dependendo de quem o fizesse (GARCIA, 2016, pp. 33-34).
}

Todos os pontos estabelecem e desenvolvem conexôes. Nâo há um centro, a unidade é ilusăo que mais distancia do que aproxima. Mesmo a imagem acima, que parece estar completa, poderia ser continuada com várias outras linhas saindo de qualquer ponto em qualquer direçấo, sobrepondo-se. Cada um que se coloca na posiçấo de ligar os pontos seguirá seu próprio fluxo, isto é, o movimento do próprio corpo e suas intensidades afetivas. Sobre Marília Garcia podemos dizer que seus livros estabelecem linhas que se cruzam umas sobre as outras, criando conexóes. As intensidades percorrem a geografia criada por sua máquina literária. O desejo maquínico produz linhas de fuga, produz um "para fora" constante: a autora é o cartógrafo devora, é o corpo que produz, é o desejo que se transforma em poema. Mas como o desejo sempre escapa à ordem da representaçăo, suas lascas produzem novas linhas de fuga.

Marília Garcia parece querer construir um edifício que nunca se conclui. Em outros termos, seu trabalho é um trabalho sobre as ruínas de um edifício jamais construído, mas imaginado sempre de uma maneira diferente. A poesia como teste, experimentaçăo, ensaio: direçôes incertas cujo centro nunca é alcançado. A autora está em um constante processo de desterritorializaçáo e territorializaçáo de sua poesia, como se jogasse com elementos díspares e irreconciliáveis, tudo para mostrar que em poesia o gesto que traça a linha pode ser mudado.

O título de seu último livro, Parque das ruínas, sugere jogo: "parque" é também o lugar da brincadeira, da descoberta e da imaginaçăo. É também o livro no qual pela primeira vez Marília Garcia usou fotografias em sua composiçáo, fazendo com que estas complementassem o texto escrito. No entanto, o que buscamos nas fotografias nunca está nelas, mas fora - serăo signos? Há, nesse playing com o leitor, uma busca: a do "tu" como cúmplice.

Nesse sentido, as fotografias constituem-se como linhas de fuga, jogando nosso olhar para fora, como se nos convocasse a também procurar pelo infraordinário. Novamente o infraordinário de Georges Perec aparece como busca desejada pelo sujeito do poema, que lança seu olhar para além, para um fora que nos arrasta junto. 0 olhar do leitor/expectador/ouvinte tenta acompanhar, mas como ter acesso se, assim como o "eu" do poema, também năo temos acesso ao que o "outro" faz ou vê?

Nessa geografia literária, Marília Garcia ensaia, testa, experimenta, joga, performatiza. Sobre seu primeiro livro, 20 poemas para o seu walkman, o poeta argentino Aníbal Cristobo escreveu algo que serve como uma consideraçăo solta para este texto: "Acho que dentro de algum tempo, para se referir a esses sons que você traz aqui, as pessoas dirăo: 'me sentia dentro de um poema da Marília, e ouvia minha voz, mas o sentido continuava longe, e só conseguia entender que ia me afastando de alguma coisa - que também era eu"' (CRISTOBO apud GARCIA, 2007, p. 80). A soltura da consideraçáo se refere ao fato de ter que concluir (náo concluindo!) este texto. Mas sabemos que ele deixa uma abertura (nâo uma, mas várias, aliás!), que fica a cargo dos poemas 
de Marília Garcia que nos colocam em deslocamento náo apenas com nosso "eu" - que julgamos ser nossa representaçáo mais fiel -, mas também com o que até hoje julgamos sabemos sobre poesia ou poema ou ensaio... É a intençăo do rizoma: năo começar nem concluir, mas ser intermezzo, inter-ser, estar sempre entre. 


\section{REFERÊNCIAS}

ALFERI, Pierre. Rumo à prosa. Trad. Masé Lemos e Paula Glenadel. Alea, Rio de Janeiro, v. 15, n. 2, p. 423-427, jul./dez., 2013.

COLLOT, Michel. O sujeito lírico fora de si. Trad. Alberto Pucheu. Revista Terceira Margem, Rio de Janeiro, ano 9, n. 11, pp. 165-177, 2004.

COLLOT, Michel. Poesia, paisagem e sensaçăo. Trad. Fernanda Coutinho. Revista de Letras, n. 34, vol. 1, jan./jun., pp. 17-26, 2015.

COLLOT, Michel. Rumo a uma geografia literária. Trad. Ida Alves. Niterói, n. 33, v. 2, pp. 17-31, 2012.

COMBE, Dominique. A referência desdobrada: o sujeito lírico entre a ficçâo e a autobiografia. Trad. Iside Mesquita e Vagner Camilo. Revista USP, Sáo Paulo, n. 81, dez./fev., pp. 112-128, 2009-2010.

DELEUZE, Gilles \& GUATTARI, Félix. Mil platôs: capitalismo e esquizofrenia. vol. 1. Trad. Aurélio Guerra Neto e Célia Pinto Costa. Rio de janeiro: Ed. 34, 2011.

DELEUZE, Gilles \& GUATTARI. Espinoza e as três Éticas. In: Peter Pál Pelbart. Rio de janeiro: Ed. 34, 2011, pp. 177-193.

. Crítica e clínica. Trad.

DI LEONE, Luciana. Olhando a poeira: o método e a poesia de Marília Garcia. In:SCRAMIN, SUSANA et al. (Orgs.). 0 duplo estado da poesia: modernidade e contemporaneidade. Săo Paulo: Iluminuras, 2015, pp. 125-134.

FREUD, Sigmund. Uma dificuldade da psicanálise [1917]. In: Obras completas. v. 14. Trad. Paulo César de Souza. Săo Paulo: Companhia das Letras, 2010, pp. 240-251.

GAGNEBIN, Jeanne Marie. 0 camponês de Paris: uma topografia espiritual. In: Sete aulas sobre linguagem, memória e história. Rio de Janeiro: Imago, 2005, pp. $\overline{\text { 53-1 }} 62$.

GARCIA, Marília. 20 poemas para o seu walkman. Săo Paulo: Cosac \& Naify, 2007.

GARCIA, Marília. Câmera lenta. Săo Paulo: Companhia das Letras, 2017.

GARCIA, Marília. Engano geográfico. Rio de Janeiro: 7Letras, 2012.

GARCIA, Marília. Paris náo tem centro. Rio de Janeiro: 7Letras, 2016.

GARCIA, Marília. Parque das ruínas. São Paulo: Luna Parque, 2018.

GARCIA, Marília. Um teste de resistores. Rio de Janeiro: 7Letras, 2014.

GARCIA, Marília. Um teste de solidăo: passagens em Emmanuel Hocquard. In: PEDROSA, Celia \& ALVES, Ida (Orgs.). Subjetividades em devir: estudos de poesia moderna e contemporânea. Rio de Janeiro: 7Letras, 2008, pp. 239-247.

GARRAMUN̂O, Florencia. A poesia contemporânea como confim. In: SCRAMIN, Susana et al. (Orgs.). Linhas de fuga: poesia, modernidade e contemporaneidade. Sáo Paulo: Iluminuras, 2016, pp. 11-17.

GARRAMUN̂O, Florencia. Frutos estranhos: sobre a inespecificidade na estética contemporânea. Trad. Carlos Nougué. Rio de Janeiro: Rocco, 2014. 
LUDMER, Josefina. Literaturas pós-autônomas. Trad. Flávia Cera. Sopro, n. 20, jan., pp. $1-4,2010$.

NANCY, Jean-Luc. À escuta. Trad. Fernanda Bernardo. Belo Horizonte: Ediçōes Chăo de Feira, 2014.

NANCY, Jean-Luc. Fazer, a poesia. Trad. Leticia Della Giacoma de França e Janaina Ravagnoni. Alea, Rio de Janeiro, vol. 15, n. 2, jul./dez., pp. 414-422, 2013.

PAZ, Octavio. Signos em rotaçăo. In: . 0 arco e a lira. Trad. Ari Roitman e Paulina Wacht. Săo Paulo: Cosac \& Naify, 2012, pp. 259-291.

PEREC, Georges. Aproximaçōes do quê? Trad. Rodrigo Silva Ielpo. Alea, Rio de Janeiro, vol. 12, n. 1, jan./jun., pp. 178-180, 2010.

RIVERA, Tania. O retorno do sujeito: sobre performance e corpo. In: 0 avesso do imaginário. Săo Paulo: Cosac \& Naify, 2013, pp. 17-45.

ROLNIK, Suely. Cartografia sentimental: transformaçóes contemporâneas do desejo. Porto Alegre: Sulina; Editora da UFRGS, 2011.

ROSENFELD, Anatol. Teoria dos gêneros. In: 0 teatro épico. Sâo Paulo: Perspectiva, 2011, pp. 13-36. 